\title{
$\begin{array}{r}\text { WAGENINGEN } \\ \hline\end{array}$
}

\section{Sustainability governance of chains and networks: a review and future outlook}

Bush, S. R., Oosterveer, P. J. M., Bailey, M. L., \& Mol, A. P. J.

This article is made publically available in the institutional repository of Wageningen University and Research, under article 25fa of the Dutch Copyright Act, also known as the Amendment Taverne.

Article $25 \mathrm{fa}$ states that the author of a short scientific work funded either wholly or partially by Dutch public funds is entitled to make that work publicly available for no consideration following a reasonable period of time after the work was first published, provided that clear reference is made to the source of the first publication of the work.

For questions regarding the public availability of this article, please contact openscience.library@wur.nl.

Please cite this publication as follows:

Bush, S. R., Oosterveer, P. J. M., Bailey, M. L., \& Mol, A. P. J. (2015). Sustainability governance of chains and networks: a review and future outlook. Journal of Cleaner Production, 107, 8-19. DOI: 10.1016/j.jclepro.2014.10.019

You can download the published version at:

https://doi.org/10.1016/j.jclepro.2014.10.019 


\title{
Sustainability governance of chains and networks: a review and future outlook
}

\author{
Simon R. Bush*, Peter Oosterveer, Megan Bailey, Arthur P.J. Mol \\ Environmental Policy Group, Wageningen University, Hollandseweg 1, 6706 KN, Wageningen, The Netherlands
}

\section{A R T I C L E I N F O}

\section{Article history:}

Received 4 March 2014

Received in revised form

6 October 2014

Accepted 8 October 2014

Available online 16 October 2014

\section{Keywords:}

Supply chain management

Global commodity chain

Global value chain

Global production networks

Corporate social responsibility

Governance

\begin{abstract}
A B S T R A C T
This paper reviews the extent to which sustainability governance has been integrated into the literature on sustainable chains and networks. The analysis brings together four main approaches to chains and network studies - supply chain management (SCM), global commodity chains (GCC), global value chains (GVCs) and global production networks (GPNs) - to examine how and the extent to which sustainability and sustainability governance are conceptualised and incorporated into their analytical frameworks. The results point to a shift in this combined literature from conceptualising the formation of global chains and networks as sites of inequality under conditions of globalisation, towards a renewed vision on the potential of chains as a site for social and environmental reform. Overall, however, we conclude that the literature on global chains and networks has not adequately conceptualised distinct modes of sustainability governance. In response, we offer an amended typology for identifying how firm and non-firm actors govern sustainability in chains, of chains and through chains in globalised commodity production and consumption. The paper finishes with an exploration of the research frontiers, challenges and continuing potential of chain and network studies to understand the governance of sustainability and a call for further academic debate on the kinds of integrated governance arrangements necessary for future sustainability reform through hybridised public-private economic practice.
\end{abstract}

(C) 2014 Elsevier Ltd. All rights reserved.

\section{Introduction}

In the current era of globalisation, two major developments have changed the way societies aim for sustainable production and consumption. First, production and consumption processes are no longer taking place within the boundaries of one single country or nation-state, but are increasingly transboundary in nature. Supply chain management (SCM), global commodity chains (GCCs), global value chains (GVCs) and global production networks (GPNs) are concepts that have emerged widely in the literature to analyse and understand the transboundary organisation of production and consumption. Second, and in relation to the first point, state authorities have proved to be increasingly unable to regulate and govern the sustainability of globalised production and consumption. In response new forms of hybrid or private sustainability governance arrangements and institutions have emerged that target both products and production processes, and involve primary producers, processors, traders, retailers, and/or consumers

\footnotetext{
* Corresponding author. Tel.: +31 (0)317 483310 .

E-mail addresses: simon.bush@wur.nl (S.R. Bush), peter.oosterveer@wur.nl (P. Oosterveer), megan.bailey@wur.nl (M. Bailey), arthur.mol@wur.nl (A.P.J. Mol).
}

(Silva-Castañeda, 2012). Examples include corporate social responsibility, the sustainable trade movement, various codes, standards and certification schemes, private interest governance schemes, and public and private auditing. After nearly two decades of implementation and research on non-state governance approaches, questions are emerging around their relevance for changing social and environmental practices of global production and consumption.

The theorisation of international private governance structures has focused on two broad sets of questions. First on the credibility, authority and power of economic actors in determining control over allocating financial, material and human resources in global chains (Boons and Mendoza, 2010; Gereffi et al., 2005), and second, on the design, content and implementation of quality standards and certification schemes (e.g. Busch and Bain, 2004; Marsden, 2004). The turn to sustainability and private governance in global production and consumption has bridged these two literatures, moving beyond global economic practice, to identify arrangements that can be considered "a political settlement and institution building project" pursued by social movements, international NGOs, private companies and states (Bartley 2010, cited in McCarthy et al., 2012 p. 564). The burgeoning literature on chains 
and networks has given attention to these questions on sustainability governance. But the scope of these studies is vast, extending well beyond sustainability to focus on the transnational flow of goods, information, finances and regulation more broadly. It is therefore timely to clarify the contribution of the chains and networks literature to sustainable transboundary production and consumption, by analysing its theoretical coherence and contribution to our understanding of private sustainability governance.

The aim of this paper is threefold. First, we identify how the metaphors of 'chains' and 'networks' have been used to organise analysis on global production and consumption and the extent to which sustainability and governance has been dealt with in this literature. We do this by taking a chronological perspective of the four approaches to chains and networks studies. Second, we review and discuss the governance of the social and environmental dimensions of sustainability in chains and networks. In doing so we establish a typology of governing sustainability in chains, of chains and through chains to understand how firm and non-firm actors influence decisions over sustainability in globalised commodity production and consumption. Finally, we turn to an exploration of key research frontiers and challenges, with a view to understand the continuing potential of chains and networks studies for sustainability governance.

\section{Global value chains: development, approaches, themes}

Four separate but related approaches can be distinguished that attempt to explain global production and consumption through the structure and function of chains and networks. The first, based on business administration, economics, and information technology studies in the 1990s, is the management of supply chains and networks. The second and third approach, global commodity chains and global value chains, are more closely related; based on political economy, World System theory, and industrial sociology. The fourth approach is that of global production networks, also based on World System theory, and aimed at a geographical understanding of how production and distribution is influenced by firm and nonfirm interaction. While all four approaches were not developed to answer questions related to the 'greening' or sustainability of production and consumption, they have made contributions in different ways. Here we give a brief overview of where each approach has come from and how they relate to each other.

Porter (1985) was one of the first to use the organisational metaphor of a 'chain' to describe how different stages of production are related and collectively contribute to the value and character of a final product. He and others questioned how the form and function of inter- and intra-firm relations, transaction costs, logistical infrastructures, product life-cycle management, standardisation, and tracking and tracing systems contributed to new supply chain management structures. These studies focused on the inherent paradox that while globalisation diminishes the importance of where firms locate their business, geographic concentrations of interconnected companies are a key feature of many, if not most, sectors (Porter, 2000). Understanding the geographical position of firms in the global economy therefore raises questions about the competitive advantage associated with micro-economics of competition and location (Porter, 2000), as well as the value associated with non-competitive knowledge exchange between firms (Tallman et al., 2004). The industrial cluster literature is replete with examples from both resource dependent sectors, such as wine, coffee and paper and pulp, but also with non-resource dependent sectors such as apparel and electronics (e.g, Aylward, 2004; Davis et al., 1992; Giuliani, 2007). Critics of this literature have pointed out the risk of promoting industrial clusters, for competitive or other benefits, including environment, on the basis of international competitive advantage, largely because of a lack of theoretical development and empirical evidence (Martin and Sunley, 2003; Yu and Jackson, 2011).

Over the same period of time 'chain studies' emerged from the macro-scale, long-term orientation of World Systems theory to analyse the wider political economic conditions of production and consumption, laying the ground for the second tradition. Hopkins and Wallerstein (1977) introduced the concept of "commodity chains' to understand the dependencies in a globalising economy between sites of production in core economies and sites of production in peripheral economies. Building on the political economy approach of World Systems theory, commodity chains provided a basis for understanding the evolution of a global division of labour in the world economy, the unequal distribution of rewards among the different activities making up a chain, and the spatial and social configuration of production-consumption relations in response to cyclical shifts in the global economy (Bair, 2009). The overriding focus was on the structure of linear connections between (low added-value) commodity production in 'peripheral' regions of the world-economy with (high added-value) products, retail and consumption in the 'core' (Hughes and Reimer, 2004a). But while the approach was successful in making these connections in the global economy explicit, the linear dimension of these chains limited the incorporation of agency, internal chain relations, domestic economic factors, and the consequences/opportunities of globalisation for international development. Although natural resources were a focus of these commodity chain studies, and World Systems theory made clear links to global resource equity, no substantive links were made to the environmental reform or 'greening' of these chains.

Moving beyond World Systems theory, but continuing the relational dimension of production and consumption, Gereffi (1994, 1995) developed the concept of global commodity chains (GCC) to understand processes of global economic integration through the role of firms as lead agents in chains extending from and through industrialising and developing states. Bair (2009) argues that the GCC approach extended beyond the structural political economy of World Systems theory, so prevalent at the time (Friedmann, 1993; Goodman and Watts, 1997; McMichael, 1994), by focusing on how lead firms construct and manage international production. GCC scholars also drew upon the more disparate notions of culture, quality and convention from the French filière approach (Raikes et al., 2000) and the consumer-orientation of systems of provision (e.g. Fine and Leopold, 1993). Gereffi's GCC framework included four key dimensions: (1) the material flow of inputs and outputs, (2) the geographical configuration of chain actors over global space, (3) the kind of coordination and control expressed by lead firms, and (4) the wider institutional influences over organisation and structure of chains. Exploring these dimensions helped Gereffi to capture the role of firms within the systems of coordination that organise international production and consumption. And, again, while attention remained focused with the distributional and coordination effects related to natural resources, sustainability did not emerge as a theme until much later (e.g. Klooster, 2005).

The conceptual turn to chain governance started with Gereffi's (1994) introduction of what he termed 'drivenness' in chains, distinguishing two forms. The first, producer-driven chains, is characterised by the concentration of capital and technological knowhow allowing producers to dominate the value chain (e.g. in automobiles). The second form, buyer-driven chains, consists of chains dominated by distributors and retailers via their control over the branding, design and market functions (e.g. garments). Buyerdriven commodity chains in particular reflected the experience of many developing countries gradually being integrated in the global 
economy through the production of industrial products, but without having the power to dominate the value chains. According to some scholars, these studies focused too much on primary products (e.g. agricultural products, oil, minerals) or low-valueadded basic goods (e.g. simple garments), limiting the wider relevance of the chain approach to complex products. The initial dichotomy of Gereffi (1994) between producer-driven and buyerdriven chains was also critiqued as too simplistic (Raikes et al., 2000; Sturgeon, 2009; Talbot, 2009). In response, the GCC framework was gradually adapted and refined at the end of the 1990s into global value chain (GVC) analysis.

The shift from GCC to GVC analysis was incremental rather than paradigmatic. Some scholars have even argued that the shift is largely terminological (Daviron and Gibbon, 2002), with only a somewhat broader scope of chain activities and end products (Gereffi et al., 2001). Others have argued that while GVC analysis draws on the GCC framework, it reflects a stronger focus on transaction cost economics and industrial organisation (Sturgeon, 2009). Nevertheless, as Ponte and Sturgeon (2013) point out, there continues to be fundamental theoretical differences between the GCC and GVC frameworks. First, the term 'value chain' corresponds to the concept of value added, which fits with an overall focus on economic development, where human, natural and material capital is transformed into economic rents and accumulated through an interconnected capitalist system. Second, with value chains the shift is away from the narrow 'drivenness' of chains, to a more socially embedded understanding of coordination in terms of the complexity of information, the codification of that information and the capabilities of actors in the chain to interpret and act upon that information (Gibbon et al., 2008). This led to the construction of a now often quoted matrix of five governance structures (Gereffi et al., 2005): market, modular, relational, captive, and hierarchy. This spectrum of market coordination and governance emphasises changes in the complexity of codifying information between chain actors, and the capability of suppliers to interpret and act upon this information.

Despite being widely applied, critics have argued that this framework of GVC governance is too general to explain the complexities of coordination between different nodes of the chain (Gibbon and Ponte, 2005). Likewise, the attention to coordination/ linkages has meant that organisation and activity within specific nodes of the chain are not well understood, and information flows along chains are often considered as unidirectional (Derudder and Witlox, 2010; Sassen, 2010; Vind and Fold, 2010l). The global scope of GVCs has also been questioned, given that a considerable amount of trade in large economies is still domestic. Moreover, the global connections that have attracted attention focus largely on flows from Southern producers to Northern consumers, rather than the other way around or on the increasingly important South-South trade (Murphy, 2008; Raghuram, 2004; Reardon et al., 2007). The GVC approach has also been criticised for not taking into consideration the coordinating role non-firm actors, other than related to quality standards (Nadvi, 2008; Ouma, 2010; Palpacuer, 2010). Finally, and perhaps most relevant to our further discussion, GVC analysis has been criticised for focusing too narrowly on vertical dimensions of inter-firm coordination when trying to explain the incorporation of sustainability goals in global economic production.

Despite these critiques, both GCC and GVC scholars have highlighted how vertical relations between producers, distributors and consumers are also a product of complex flows between 'horizontally' networked actors beyond the chain (building largely on earlier work by Crang (1996); Fine et al. (1996); Hughes and Reimer (2004b); Leslie and Reimer (1999). As first introduced by Fine (1993) and Glennie and Thrift (1993), the elaboration of horizontal dimensions in value chains recognises the wider social relations of production and consumption around the chain. In doing so they built on World Systems theory by embedding economic practices within the broader 'external' processes that shape the construction and operation of production and consumption (Bair, 2009). Sustainability has also emerged as a key horizontal theme in GVC analysis, incorporating environment, labour and gender (Bolwig et al., 2010; Mitchell and Coles, 2011) into understanding vertical coordination.

A fourth alternative framework that also captures these horizontal and vertical dimensions is the global production network (GPN) approach (see Coe et al., 2008; Hughes et al., 2008; Whatmore and Thorne, 1997). GPN analysis takes as its object "the globally organised nexus of interconnected functions and operations by firms and non-firm institutions through which goods and services are produced and distributed" (Coe et al., 2004, p. 41). Building on actor-network theory (e.g. Busch and Juska, 1997; Murdoch, 2000), commodity circuits (Leslie and Reimer, 1999) and convention theory (Daviron and Gibbon, 2002), the GPN approach has furthered understanding of global economic organisation beyond productivism by strongly emphasising the socially and territorially embedded nature of production and consumption (Bair, 2008; Hess, 2004). This approach has developed largely as a response to the perceived weaknesses of GVC analysis presented above. It is argued that the network perspective of GPNs allows for greater attention to non-firm actors in structuring global economic relations, and the regulatory and institutional contexts which shape production (Coe and Hess, 2005; Hess, 2004). As argued by Coe (2012), the emphasis on networks between and within 'territories' also underlines the spatial geographies of these economic relations in the context of globalisation, allowing for multiple ways of interaction between involved actors as opposed to the more structured typology of the GVC approach.

Those critical of the GPN approach argue that despite its focus on networks, the vertical/linear movement of goods from producers to consumers still structures much of the analysis. Although other flows have been brought in (e.g. financial, informational, environmental) these are often limited to those directly of relevance to the bounded problematic of 'production-consumption'. In response, attention has been given to nested processes or networks within GPNs. Examples include following financial flows through the locally embedded networks of cities (Sassen, 2010), and understanding the local social relations of production that facilitate the illegalities of ship breaking (Crang et al., 2013). Building on the geographical background of GPN analysis, these studies emphasise the importance of place in global production and consumption. However, while (networked) social relations remain a central focus, GPN researchers have not extended their approach to sustainability and the environment other than the relations of natural resource exploitation.

What is clearly evident from this short review is that while the supply chain approach focused attention on relationships around production and consumption, it is now firmly a separate approach. In contrast however, the GCC, GVC and GPN frameworks have all carried forward elements from World Systems theory, and after a period of differentiation the three approaches are once again converging (Coe, 2012; Crang et al., 2013; Ponte and Sturgeon, 2013; Yeung and Coe, 2014), to the extent that they represent strands of one distinct GCC/GVC/GPN 'family' (e.g. Dennis Wei et al., 2011; Derudder and Witlox, 2010). Indeed, in the introduction of their modular approach to GVC analysis, Ponte and Sturgeon (2013) have gone so far as to say that the differences between the frameworks are largely discursive, stressing their similar interests in mapping the spatial and organisational division of labour, the creation, capture and location of value, the institutional and regulatory processes, and the wider cultural economy influencing economic organisation. 
What we also clearly see is that while these approaches are strongly focused on the organisation of economic practice within a global capitalist mode of production, they have focused less explicitly on sustainability. Where sustainability has been discussed it is referred to in terms of how the economic order of production and consumption influences social equity and/or environmental performance. This has meant that sustainability issues have been dealt with indirectly, most often as a consequence of capitalist production. Nevertheless, the organisation of production and consumption links directly to how international private governance arrangements can influence sustainability decision making by both firm and non-firm actors in chains and networks. The rest of this paper therefore discusses how we can build on these chain and network conceptualisations to better understand how private governance arrangements are structured, and how such governance mechanisms can engage with these actors in influences over sustainability.

\section{Governing sustainability in, of and through chains}

Governance in the GCC/GVC/GPN literature has been variously defined, focusing on a range of organisational, normative and regulatory processes. A first distinction can be made between a focus on the internal drivers of economic organisation within chains, and, in response to what Mayer and Gereffi (2010) label the 'governance deficit' of GVC research, a focus on the external contribution of nonstate and non-firm actors in defining the rules through which chains are organised. Similarly, recent GPN literature has only started to systematically address how, albeit without explicit reference to 'governance', (internal) firm strategy is influenced by a range of (internal and external) inter and intra firm-non-firm interactions (Yeung and Coe, 2014). We argue that this dichotomy of internal-external also organises attempts to include the governance of sustainability in chains and networks, which in general terms refers to the ways "in which the products and the production process result from environmental, social and/or economical concerns and practices" (Cruz and Boehe, 2008, p. 1188).

Internal perspectives of governing sustainability cover two lines of scholarship. The first line focuses on a functionalist perspective of (sustainable) 'supply chain' management, which we term sustainability management in chains (see Fig. 1 for illustration). The second deals with control and the power asymmetries arising from the sustainability management of chains. Sustainability governance in chains is predominantly taken up in business management literature analysing inter and intra firm logistics, industry coordination and industrial environmental management. Whereas the governance of chains is located within the GVC tradition and focuses more on the coordination mechanisms and power relations among economic actors. It is notable that in both instances external influences over firms exist (as shown in Fig. 1), but the sustainability practices and processes being governed remain internal to the chain.

External perspectives focus on how sustainability governance is organised through production chains and networks - as a direct outcome of organisational arrangements facilitating informational flows. This perspective is developed through the addition of horizontal connections and therefore goes beyond internal chain coordination and management. Governance through (commodity or value) chains instead captures what Ponte and Gibbon (2005) consider governance as normalisation; that is, how external nonfirm actors, such as consumers, NGOs and government institutions, structure flows of information that are taken up in the norms and practices of firms and in turn influence practices within and around a particular GVC (Gibbon et al., 2008; Ponte, 2009); a dynamic illustrated by both in and out flowing arrows in Fig. 1. And
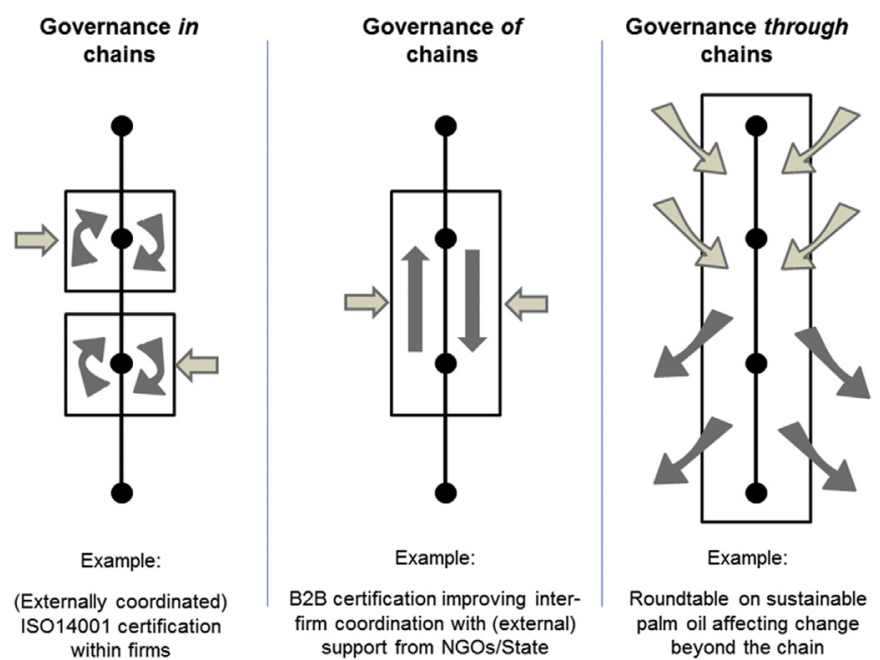

Fig. 1. Illustration of three ideal types of governing chain sustainability. Legend: Light grey arrows entering the chain indicate external governance related influences over firm actors. Dark grey arrows indicate firm related governance influences both internal and external to the chain.

from the GPN literature, it reflects recent claims that to understand firm-non-firm interaction, we need to better classify the ways in which partnership, control and bargaining influence economic practice (Yeung and Coe, 2014).

There is now a multitude of ways in which firms within chains and non-firm actors outside chains engage with, define, codify and govern sustainability. We apply our three ideal types of governing sustainability in, of and through chains (cf. Ponte et al., 2011) as a means of organising a review of the different activities, practices, management systems and organisational arrangements that broadly constitute sustainability governance.

\subsection{Governing sustainability in chains}

Governing sustainability in chains entails private firms' activities as chain actors aiming to improve their social and environmental performance from a business management perspective. Within this literature attention has been given to management systems that allow for the monitoring, measurement and control of sustainability issues in industrial processes of suppliers, and the transfer of environmental flows along the chain. The focus is largely on managerial systems based on performance indicators that can be used to create efficient control over suppliers to minimise environmental and social risks. Systems such as the environmental management ISO 14001 and social accountability standard SA8000 are prime examples (see Kautto, 2006). Processes of production are made legible for downstream suppliers and the risks of supply can be incorporated into purchasing decisions. The focus on 'greenproducts' draws in other management and environmental assessment tools such as life-cycle analysis (LCA), again with a view to create performance indicators, efficiencies and to minimise functional and reputational risk. Wider public reporting is done through the Global Reporting Initiative framework (Hopkins, 2004) that contains a large number of indicators to measure performance in social, environmental and economic respect.

As argued by Seuring and Müller (2008), sustainable supply chain management is interested in the control of "material, information and capital flows", as well as finding solutions for efficient forms of "cooperation among companies along the supply chain while taking goals from all three dimensions of sustainable development, i.e., economic, environmental and social" (p. 1700). This 
perspective is inward looking in that it reflects conventional perspectives of supply chain management to improve chain relations in order to achieve a competitive advantage (Handfield and Nichols, 1999). It is in this sense that we frame the governance of sustainability in value chains as an internal perspective on the 'greening' of practices within the chain.

The literature recognises that corporations are involved in improving their social and environmental performance and that they are increasingly required by different groups in society to do so (Bartley, 2003; Carroll and Shabana, 2010; Miller et al., 2010; Windsor, 2006); although this is still largely restricted to OECD countries (Jamali and Mirshak, 2007). As Gold et al. (2010) observe, there are pressures from different stakeholder groups that trigger firms to effectively incorporate sustainability issues in their supply chain management. Increasingly, private companies are considered responsible for the external effect of not only their own production process, but also of their products across their entire lifecycles (De Bakker and Nijhof, 2002). In response, different actions may be undertaken by these companies and they can be summarised under the heading of Corporate Social Responsibility (CSR). Different questions emerge from this observation (Seuring and Gold, 2013), including: why do firms engage in CSR policies? What capabilities are required for a firm to deal with sustainability challenges? And what are the appropriate management strategies that build sustainability within firms?

Private corporations may engage in CSR for different reasons. They may consider it in their long-term interest to secure the social and environmental base of their enterprise, or, by being pro-active in this respect, they may hope to ward off government regulations and realise additional profit from an emerging demand for sustainable products. There is some evidence of first mover rewards (Asif et al., 2013) and competitive advantages (Orlitzky et al., 2011), but others doubt whether there are any real financial benefits in adopting this strategy, beyond some cost reductions (Carroll and Shabana, 2010; Windsor, 2006). Normative support for CSR is based on the argument that "a company should balance and trade off the competing claims of customers, suppliers, employees, investors and the communities in which it operates" (RSA 1995, cited in Smith, 2003). However, much of the debate on CSR is moving away from ethical practice (Vogel, 2010; Wheeler et al., 2003) and towards determining the business case for CSR (also see Porter and Kramer, 2006, 2011). According to Carroll and Shabana (2010), this case includes a combination of: (1) reducing costs and risks; (2) strengthening legitimacy and reputation; (3) building competitive advantage; and (4) creating win-win outcomes through synergistic values. CSR can be promoted by a company in collaboration with other firms within a particular supply chain to compete with other supply chains. But as argued by Gold et al. (2010), the management of information, material and financial flows within one company then has to be coordinated with others in the supply chain to gain this competitive advantage, which in many cases may prove a challenge.

Whatever the particular reason for a firm to develop a CSR policy, it is generally accepted that strategies will only be successful when adopted at every level of a corporation (Asif et al., 2013; Nijhof and Jeurissen, 2006). Ongoing debate focuses on different CSR strategies, management responsibilities and the effects of CSR on social and environmental outcomes. Responsible chain management requires a continuous alignment of expectations within an organisation and the existing, realised or unrealised, expectations of stakeholders (De Bakker and Nijhof, 2002). This reference to stakeholders illustrates that the debate on sustainability governance also entails a shift away from shareholders and investors alone (Wagemans et al., 2013) when discussing the future strategy of a firm (Seuring and Müller, 2008). By referring to stakeholders,
CSR-strategies intend to include everyone who has a legitimate interest in a corporation's activities. The legitimacy of a private corporation is therefore no longer only based on its economic performance but also on its concrete promotion of social and environmental interests. This shift is variously referred to as 'people, planet and profit', 'triple bottom line accounting' or the need for a company to have a '(social) license to produce'.

Many studies analyse the assets, capabilities and organisational competences to successfully implement CSR policies. Particular attention is given to coordination and collaboration, such as supply chain management and strategic purchasing, because of the interdependencies between firms when changing social and/or environmental practices (Gold et al., 2010). De Bakker and Nijhof (2002) underline a distinction between the conceptualisation phase and the implementation phase in the process of building responsible chain management when responding to stakeholder interests. In response, they developed a 'capability assessment framework', which allows firms to identify gaps and specific needs in their organisational capabilities. The specific requirements also depend on the sector, the size of the firm and the ability of the firm to re-align their internal capabilities to address the wider dynamic environment shaping CSR (Nijhof and Jeurissen, 2006).

Finally, there is an ongoing tension between voluntary and legislated CSR policies when trying to balance the need for credibility and flexibility. Various authors argue that the dynamic nature and context of CSR means that externally imposed (one-size-fitsall) approaches are counterproductive (Asif et al., 2013; Carroll and Shabana, 2010; Porter and Kramer, 2006; Smith, 2003). However, CSR is rarely if ever implemented in isolation from the influence or oversight of NGOs or state actors. A variety of CSR tools and policies promoted by governments in OECD countries, through subsidies, regulatory relief, or direct legislation, have provided a requisite level of credibility. But they have also led to reduced flexibility for change and adaptation. For example, state requirements for extended product responsibility (EPR) have made companies responsible for products (including waste from end-oflife products) beyond the factory level; imposing legal obligations for upstream companies in the value chain to take responsibility for downstream collection and recycling of packaging and waste (e.g. Gui and Atasu, 2013; Lifset et al., 2013). Whether and how such state requirements develop into the future is dependent on the extent to which CSR can moving beyond an internal, firm level set of tools and processes.

\subsection{Governing sustainability of chains}

Governing the sustainability of chains is directly related to Gereffi et al.'s (2005) typology of modes of coordination that a lead firm can exercise over chain actors. From a sustainability perspective, lead firms are mostly downstream buyers in developed countries setting the conditions for market access and in doing so drive changes in production practices of upstream developing country actors (Cattaneo et al., 2013; Humphrey and Schmitz, 2002; Jeppesen and Hansen, 2004). By requiring certain production qualities and standards, and by transferring knowledge and technology, lead firms can contribute to changes in their suppliers' environmental performance (Jeppesen and Hansen, 2004; Ponte and Gibbon, 2005). Whereas production standards are associated with managing production risks, including reputational risks associated with poor social and environmental performance, knowledge transfer between actors within a chain reduces the burden on individual actors to engage in positive information exchange that can lead to improved production practices (Simon, 2000). In fact, for those countries that have lagged behind in international integration, advanced sustainability information and 
knowledge is often not readily available and must be obtained elsewhere, and transfer within chains is one way for that knowledge to be acquired (Sturgeon and Gereffi, 2009). As argued by Gibbon and Ponte (2005), vertical coordination is also important to help foster trust and confidence between value chain actors, and this can in turn facilitate investments in sustainability 'upgrading' by upstream actors.

In general terms, upgrading refers to strategies to "make better products, make them more efficiently, or move them into more skilled activities" (Humphrey and Schmitz, 2002, p. 19), as a result of increased competition forcing them "to perform the same activities, but more efficiently, or change the activities they undertake" (Humphrey and Schmitz, 2000, p. 3). The implication is that faced with this competitive pressure economic actors (nations, firms and workers) "move from low-value to relatively high-value activities in global production networks" (Gereffi et al., 2005, p. 171). According to Humphrey and Schmitz (2002) this can be achieved in four ways: (1) Process upgrading: reorganising the production system to transform inputs into outputs more efficiently; (2) Product upgrading: moving into more sophisticated product lines; (3) Functional upgrading: increasing the overall skill content of activities through acquisition of new functions; or (4) Inter-chain upgrading: firm or clusters move into new productive activities (from one industry to another). Despite claims that improved sustainability performance can provide a competitive advantage for firms (Porter and Linde, 1995), and that upgrading is a key strategy for governing sustainability (Gereffi et al., 2001; Humphrey and Schmitz, 2002), upgrading was not originally related to improvements in either environmental or social dimensions of production practices.

Environmental upgrading has been defined as "the process by which economic actors move towards a production system that avoids or reduces the environmental damage from their products, processes or managerial systems" (De Marchi et al., 2013, p. 65). If moving from lower value to higher value activities, upgrading for sustainability presupposes that a sustainable product will in fact entail higher value, representing higher demand from downstream actors for environmentally or socially sustainable goods (De Marchi et al., 2013). This is often linked with an understanding that demand for upgrading comes from either the potential for an economic competitive advantage or from lead firm sourcing strategies that are influenced by the expectations of an array of both firm and non-firm actors, including retailers, consumers, NGOs and government bodies (Dolan and Humphrey, 2000; Orsato, 2009; Seuring and Müller, 2008). As argued by Staritz and Reis (2013), the increasing prevalence of standards and regulations, often set by importing countries, and sustainable sourcing strategies communicated by downstream actors, has meant that upstream actors in producing countries regularly face incentives to consider sustainability in their upgrading strategies.

However, other forms of sustainability upgrading have also been observed. Instead of moving from lower value to higher value activities, firms may choose strategies that reduce environmental risks while maintaining a particular market segment, or reduce efficiencies to compete in lower value market segments. As such upgrading is not necessarily about moving 'up' the chain, but may also lead to down-grading or out-grading (Mitchell and Coles, 2011; Ponte and Ewert, 2009). Examples of these diversified strategies (not all related to environment) have been seen in the wine (Ponte and Ewert, 2009), aquaculture (Khiem et al., 2010) apparel (Pickles et al., 2006), home furnishings (De Marchi et al., 2013), and the agro-foods sectors (Gibbon and Ponte, 2005; Mitchell and Coles, 2011; Staritz and Reis, 2013). The particular strategy chosen may reflect the challenges of meeting quality requirements or price pressure by upstream actors in buyer driven chains. When developing economies and producers are involved, attention has not only been given to the capital required to adopt a particular upgrading strategy, but also to their conditions and capabilities to benefit from any strategy adopted. As such, social and economic sustainability have also become outcomes of upgrading (Gereffi et al., 2001; Humphrey and Schmitz, 2002); a theme taken up in great detail through the Capturing the Gains Summit and network (e.g. Barrientos, 2013; Kaplinsky, 2000; Rossi et al., 2013). But when small-holder inclusion is dependent on external support (Bolwig et al., 2011), within-chain coordination may fall short of fully facilitating upgrading strategies and therefore may fail to realise transitions to sustainable production.

Sustainability upgrading is also not the sole remit of the private sector, as it can be driven by states through setting targets for 'environmental' or 'green' public procurement. The purchasing power of the public sector is seen as a direct way of stimulating market demand for sustainable products and in turn stimulating demand for sustainable production practices. Better performing governments of OECD countries now register $23-50 \%$ of all public purchases as 'green' or 'sustainable'; equivalent to $10-18 \%$ of GDP (Kataoka, 2006). There is also evidence that non-OECD countries, in both Asia and Africa, are taking up public procurement policies (Agaba and Shipman, 2007; Bolton, 2008; Ho et al., 2010; Singh, 2010). including local sourcing of food, fair trade, organic and sustainable food, furniture, computers, clothing and building materials (e.g. Li and Geiser, 2005; Morgan and Sonnino, 2007; Parikka-Alhola, 2008; Rwelamila et al., 2000), the management of waste flows (Sonnino and McWilliam, 2011), and the establishment of standards for assessing the environmental or social performance of contracts (Bolton, 2008; Preuss, 2009; Srivastava, 2007). While the impact of public procurement can be direct, in terms of harnessing the considerable purchasing power of states, there is also growing evidence (Ho et al., 2010) that green public procurement has advanced similar procurement practices in the private sector.

Evidence shows that by stimulating upgrading, lead firms can have a direct influence over sustainability practices in global value chains. However, despite this support for the governance of sustainability in chains through lead firm coordination, limited connection has been made with the literature focused on governing sustainability in chains as reviewed above. Indeed, two comprehensive reviews on sustainability in supply chains carried out in 2007 and 2008 failed to mention upgrading as a mechanism (Seuring and Müller, 2008; Srivastava, 2007). There is therefore ground for greater integration between the literature on sustainability governance in and of value chains, in particular focusing on the role of CSR in upgrading both firms and chains. In analysing environmental upgrading the role of external actors has been better covered, as evidenced by the attention paid to the role of NGOs and states in public procurement. This then turns our attention to a wider understanding of governing sustainability through chains.

\subsection{Governing sustainability through chains}

Governing sustainability through chains involves a set of normative and regulatory practices that use the chain as a conduit for influencing the social and environmental conditions of production and consumption. But unlike the former two categories, governing through chains is neither understood as firm-level CSR systems, nor as inter-firm coordination. Instead it is a broader level of governance that captures the interaction between the chain and its firm actors with a wider set of networked actors and activities that collectively steer sustainable production and consumption practices. Civil society organisations often play a key role in initiatives of governing through chains. In this way it relates more the 
network oriented GPN approach than the more linear GCC and GVCs approaches - despite all now referring to interactions between chain and non-chain actors. Understanding sustainability through value chains opens up critical questions around the form, function and impact of wider governance arrangements such as multi-stakeholder initiatives (MSIs) and voluntary certification schemes. It also relates to questions raised by a growing number of scholars (e.g. Belton et al., 2010; Falkner, 2003; Fransen and Kolk, 2007; Taylor, 2005) on the limits of private governance, by contrasting incremental change of sustainable products and production processes in conventional chains, with systemic transformation of activities surrounding those chains.

MSIs have increasingly become part of the wider governing logic of private social and environmental governance. MSIs take multiple forms, but are designed to generate credibility and authority over production processes in a particular sector (Ponte, 2014; Schouten et al., 2012) based on the regulatory tools that emerge from them including standards, certification and labelling. In some instances MSIs face resistance when attempting to generate buy-in from stakeholders when defining technical definitions for standards, while in other cases, such as the Roundtable on Sustainable Palm Oil (RSPO) and the Roundtable on Responsible Soy (RTRS), they move beyond a standard setting function to create an epistemic community that establishes the legality, moral justification and consent or justification for their ongoing activity in a sector (Schouten and Glasbergen, 2011). MSIs also provide lead-firms with a means of reducing their reputational risk (McCarthy et al., 2012; Ponte and Cheyns, 2013). However, common to the different approaches is an aspiration to establish procedural practices for assessing and assuring compliance to private sustainability standards (see Boström, 2006a), upon which credibility and regulatory authority is established. As Macdonald (2014) argues, "highly visible non-state actors have politicised key supply chain decisionmaking processes" (p. 3) by advocating for the incorporation key social and environmental concerns in an era where national governments seem very reluctant to do so.

The rise in MSIs has drawn considerable attention and critique. While providing a greater voice to civil society, there is widespread concern that MSIs have not met their own goals for inclusiveness (Béné, 2005; Schouten et al., 2012; Anh et al., 2011). As variously argued, the inclusion of some groups, most notably (small-holder) producers, has been limited, with stakeholder inclusion often reduced to a performative rather than substantive output from the meetings held (Béné, 2005; Schouten and Glasbergen, 2011). As Ponte and Cheyns (2013) note, small-holder access to resources is no longer contingent on endowments alone, but also on the practices of enrolment, the format of engagement, and processes of legitimatising private forms of governance. The technical focus of MSI meetings has not allowed for wider sustainability concerns, often couched in political and social terms, to emerge in collective debates (Cashore et al., 2007). The effect has been the further marginalisation of issues that are of primary concern to already vulnerable groups of 'stakeholders' (Overdevest and Rickenbach, 2006; Porter, 1999), the dilution of more radical positions and outcomes (Falkner, 2003), and the consolidation of power and control over regulation (Miller and Bush, 2014). Schouten et al. (2012) also point to the lack of consequentiality that MSIs face when they make poor collective decisions or when there is limited uptake by industry. However, others have argued that the direct effect MSIs have on production and consumption practices (as opposed to the standards and certification they produce) is less important than the awareness, debate and civil society partnerships that they foster (Nijhof and Jeurissen, 2006). As Fortin and Richardson (2013) argue, the primary role of MSIs is not to enforce and regulate, but instead to expose what are ostensibly private processes of production to public scrutiny.
New modes of deliberation and partnership between public and private actors dealing with sustainable production and consumption are facilitated through chains and networks. Private certification standards have either been set up by NGOs in response to a perceived regulatory gap or by industry who fear over-regulation (Béné, 2005). In both cases, minimum standards are established that steer the actions of private actors in the production process. Long established questions have been asked about the content and scope of these private standards, as well as their interaction with each other in self-regulating industries and/or sectors (Mutersbaugh, 2005): whether competition leads to a 'ratcheting up' as standards seek more stringent quality outcomes (Bernstein and Cashore, 2007; Overdevest and Rickenbach, 2006), a race-tothe-bottom should they compete on market-share (Porter, 1999), or a stalemate should one lower-level standard with high market share block a more innovative standard with low market share (Bitzer et al., 2008; Miller and Bush, 2014).

A central debate in the literature is on the role of public institutions in supporting the legitimacy of private standards (e.g. Cheyns, 2011; Gulbrandsen, 2013). As Foley (2011) argues in the case of Marine Stewardship Council (MSC) certification, the extent of public resources used to facilitate the certification of private fishing activities makes it difficult to draw a clear boundary between public and private authority and responsibility (for other examples see Ha and Bush, 2010). For example, private standards interact with the state, as the standards integrate existing public (national and local) policies and coordinate the legalisation of activities in a defined functional space (Pattberg, 2006). Guldbrandsen (2013) identifies what he labels evolutionary effects of public-private interactions: 1. Public procurement policies can strengthen competition for improved private standards, while at the same time setting higher expectations in public policy; 2 . Public-policy and private standards can mutually reinforce each other when the state depends on private standards to attain public policy objectives; 3 . States can actively assert credibility over private standards when non-state programmes emerge in densely regulated sectors; and 4. Cross learning between public and private regulation can occur when certification programs disclose not only information about rules and procedures, but also information about outcomes and effects. All of these interactions exist around chain regulation, but create dynamic governance outcomes that extend beyond activities within the chain itself.

Finally, there is an emerging debate over the impact of private governance on environmental and social sustainability. The potential for certification to address these issues revolves around three ideal functions of certification - the internalisation of environmental or social externalities through market pricing, an assurance or signal of hard-to-observe organisational characteristics and practices, and a learning and technology transfer mechanism (see Overdevest and Rickenbach, 2006). However, the limitations of certification in a global context, especially when North-South relations come into play, has come under close scrutiny by scholars working across a number of sectors, including forestry (Dauvergne and Neville, 2009; Ebeling and Yasué, 2009; Pattberg, 2006), capture fisheries (Gulbrandsen, 2009; Jacquet et al., 2010), aquaculture (Bush et al., 2013; Jonell et al., 2013) and biofuels (Partzsch, 2011; Scarlat and Dallemand, 2011). Their conclusions point to concerns that standards favour certain kinds of producers, that they have narrow definitions of sustainability that don't (nor could) reflect wider 'sustainability' needs, and that they are subject to market capture rather than initiating equitable change. A smaller group (Foley, 2012; Ponte, 2008; Vandergeest and Unno, 2012) also argues that the impact of certification needs to be understood within the wider political economy they operate in, seeing support and resistance related to sovereignty and nationalism, as well as reflecting the growing power of retailers. 
Building on the GPN literature, governing through chains identifies a number of 'external' tools and approaches for extending the impact of sustainability beyond the boundaries of direct economic activity and firm actors. But there are also many links to the internal governance arrangements such as certification and chain coordination that we have categorised as in and of value chains, and that better link to the more chain centric approach of GVC analysis. An improved understanding is needed on how these different sustainability governance approaches are linked, either supporting or undermining each other, and in doing so open up questions on how the GPN and GVC approaches relate to each other in the context of private sustainability governance.

\section{Frontiers in sustainable chains and networks}

Building on this review five frontiers can be identified for research and practice related to our 'ideal' meso-theoretical typology of governing sustainability in, of and through global value chains and networks (see Table 1). In identifying five frontiers we focus on themes that relate to challenges of developing sustainable chains under changing conditions of globalisation - including emerging Southern markets, the changing role of multilateralism, the growing role of global civil society and the expectations of impact from private and public investment in sustainability governance.

Our first frontier is centred on the impact that private sustainability governance arrangements are meant or believed to have. After nearly two decades of implementation there is growing pressure to demonstrate the sustainability impacts of the various tools and schemes (MSI, labels, standards, partnerships, CSR), also in order to maintain support for the credibility of private sustainable value chain governance (Auld et al., 2008; Bäckstrand, 2006; Boström, 2006a). While growing attention has been given to the impacts of private governance arrangements (e.g. Dalal-Clayton and Sadler, 2014; Schader et al., 2014), the results remain contradictory, and there is a clear need for further research, for more case studies and for a consistent model and conceptual frameworks. In addition, we argue that all three of our types of chain governance are of relevance to the notion of 'impact' (see Table 1). Further research should therefore focus on an improved understanding of where these impacts are located - in, of and/or through chains and how positive environmental and social impacts within firms, at the level of the value chain, as well as beyond the chain can be better steered. This will improve other existing frameworks that make distinctions between material and cognitive impacts (Fuchs and Kalfagianni, 2012; Kalfagianni and Pattberg, 2011). In doing so, the debate can move beyond rule compliance to wider sustainability impacts through, for example, the formation of social movements in support or against certification (Elgert, 2012; Fortin and Richardson, 2013) or improved inclusiveness in environmental governance processes (Boström, 2006b; Nijhof and Jeurissen, 2006). Improving the scientific basis to such impact principles may provide a new area of inquiry that might move us beyond the limits to private governance arguments that are increasingly prominent in the academic literature, and return us to a more

Table 1

Research frontiers mapped against sustainability governance types.

\begin{tabular}{llll}
\hline Research frontiers & $\begin{array}{l}\text { Governance } \\
\text { in chains }\end{array}$ & $\begin{array}{l}\text { Governance } \\
\text { of chains }\end{array}$ & $\begin{array}{l}\text { Governance } \\
\text { through chains }\end{array}$ \\
\hline Impact & $\mathrm{X}$ & $\mathrm{X}$ & $\mathrm{X}$ \\
Services & $\mathrm{X}$ & $\mathrm{X}$ & $\mathrm{X}$ \\
South-South trade & $\mathrm{X}$ & $\mathrm{X}$ & $\mathrm{X}$ \\
Role of NGOs & & $\mathrm{X}$ & $\mathrm{X}$ \\
Information & & $\mathrm{X}$ & \\
\hline
\end{tabular}

nuanced understanding of governance as an ongoing multi-actor process with multiple sustainability outcomes and impacts.

The second frontier is the lack of attention that has been given to sustainability governance related to services. Earlier reviews speculated on the appropriateness of GCC analysis to the service industry and the extent to which the GCC approach would have to be modified to be more relevant to analyse and understand this sector (Clancy, 1998). Services in support of primary production have been covered to some extent. However, consumer services related to sustainability have all but been ignored. For example, scholarship on the tourism sector, which is not only the fastest growing economic sector but also the largest non-financial service industry in the world, has focused on supply chain challenges but hardly on wider questions of governance or sustainability (Adriana, 2009; Clancy, 1998; Romero and Tejada, 2011; Tejada et al., 2011). One argument has been that applying the GVC (and perhaps also the GPN) framework to service industries like tourism is limited because production and consumption occur simultaneously and often in the same geographical space (Clancy, 1998); indicating that services don't easily fit into either entirely producer-driven or entirely consumerdriven categories (Sigala, 2008). However, tourists move in global space, as do the information technology services that link them to sites of tourism. And control over information flows that steer and shape tourist practices are also increasingly being recognised a form of environmental governance (Mol, 2008). We therefore argue that the sustainability governance of services can be understood predominantly in and of chains, as environmental reform relates to firm practices and coordination between firms through information. As service sectors such as tourism continue to grow, especially with the rise of the middle-class in the global South, we are convinced that these questions will be increasingly important in understanding whether and how sustainability can be effectively linked to CSR strategies, upgrading and private environmental and social governance in the service sector.

The third frontier relates to the role that emerging markets will play in governing sustainable global production and consumption. While North-South trade flows remain the largest by volume and value, the growth of domestic markets in many countries in the South has meant that demand for imports from other manufacturing countries have increased dramatically (Kaplinsky and Farooki, 2010). China's growing influence in Africa and South Asia are often pointed to as key examples; especially in discussions of linkages between trade, aid, political influence and sustainability (Mol, 2011). Indeed a growing number of studies are following consumer goods flowing between Asia and Africa, documenting South-South sustainability issues related to second hand clothes (Brooks, 2013), cars (Brooks, 2012), and e-waste (Robinson, 2009). But China is not alone in driving this trade. Other BRIC economies, such as Brazil, are playing a growing role in South-South investments in biofuels, and in doing so become major players in the wider global political economy of food vs. fuel (e.g. Dauvergne and Neville, 2009). As the volume of these trade flows increases, new questions are emerging around the sustainability of production and consumption practices, as well as on how to govern sustainability in, of and through South-South value chains. Analysing the trajectories towards sustainable consumption and governance in these Southern economies will add to and challenge assumptions of the characteristics of sustainability transition pathways based largely on European or North American economies. These pathways also hold implications for understanding the impact of both corporate CSR policies and third-party certification standards, both of which are dependent on rising demand for sustainable production and consumption (e.g. Bush et al., 2013).

The fourth frontier relates to the changing form and function of non-governmental organisations in governing sustainability 
through chains as environmental and social advocacy is subsumed under market transformation strategies. NGO-led MSIs, labelling and certification have been key innovations in the governance of sustainability in major commodity sectors over the past two decades. But while their involvement in co-governing these chains has been as external actor, NGOs have also taken up an internal position in local value chains such as sustainable and organic food systems. Building on these 'local' experiences and the growing globalisation of the non-profit sector, it is to be expected that environmental and social NGOs will increase their role in the internal governance of chains, both as organisers and coordinators of sustainable practices at the firm level and as lead non-firm coordinators of chain activities. For example, national NGOs are involved in coordinating product and process upgrading of producers and organising exports from Benin to Europe in partnership with European NGO partners (Glin et al., 2012). In the Netherlands, the national NGO Natuur en Milieu coordinates part of the photovoltaic panel chain from China to local Dutch households, be it for a limited time period and a limited market segment (Negro et al., 2012). And in Indonesia WWF has established a trading company to stimulate the sustainable seafood market. Whether these small or partial niche chains can and will be extended to continued lead coordination by NGOs appears unlikely. It seems more likely that lead non-firm involvement in chains will require partnerships with firm actors. Or, as has been witnessed in fair trade chains, the migration of commercial activities to the firm actors once the markets have been developed, leaving NGOs to retreat and concentrate on sustainability governance through chains via standards and certification.

Finally, sustainability governance both of and through value chains faces the challenge how to deal with transparency and disclosure that have emerged as new modes of GVC governance. Falling under the wider banner of informational governance, disclosure is increasingly seen as an act of governance as it is decisive on which flows of information in which format and level of detail are available and accessible to whom (see Gupta, 2008). As such the openness of decision making or adjudication procedures that determine the content of private governance arrangements, and the disclosure of information needed to determine whether and how effective these arrangements are in reaching their goal, are key to understanding the governance of sustainability in, of and through value chains (e.g. Auld and Gulbrandsen, 2010). New questions are being asked about who provides what information to whom, both in and outside the chain; stylised by Mol (2015) as management, regulatory, consumer and public transparency. Attention is being given to the creation of new technologies that coordinate information flows and modes of communication to regulators, consumers and the general public from what once were 'private' sources of information. As greater transparency is demanded, greater oversight will be needed on the terms and credibility of disclosure practices. And questions will emerge whether, under what conditions and how transparency can run against its own success in facilitating sustainability governance (Gupta and Mason, 2014; Mol, 2010).

\section{Conclusion}

This paper has reviewed the now extensive GCC/GVC/GPN literature on sustainability governance and set an agenda for future research into sustainability governance in chains and networks. Covering the progression from earlier work on World Systems theory and industrial clustering through to global value chains, production networks and supply chain management, various strands of literature have been brought together that underscore current thinking on governing sustainable production and consumption. The repertoire of 'market transformation' policies and strategies adopted by NGOs, governments and the private sector show a wider shift in theorising sustainability governance under conditions of globalisation by supplementing themes of power and control with the pro-active role of both public and private actors. As such global chains and networks are no longer seen only as a driver of inequality under conditions of globalisation, but also a potential and actual site of social and environmental reform.

The review has also shown that despite the multitude of empirical observations of social and environmental reform, the literature on global chains and networks is rather weak in the theorisation of sustainability governance. The most direct formulation of governance is in the GCC/GVC literature, which focuses on overarching power asymmetries and coordination in global economic practice. The GPN literature has not directly dealt with sustainability governance, and the sustainable chain literature is focused specifically on technical managerial activities rather than wider steering arrangements. Sustainability governance in all of these literature is instead seen largely as a modular 'add-on' to chain organisation building on firm-level CSR goals and/or networked NGO intervention. Further work is needed to integrate current social science theorisation of sustainability governance which analyses how economic and ecological rationalities are drawn together into a framework for understanding social-environmental reform, with the wider thinking around global chains and networks.

Our categorisation of internal and external led sustainability governance is also an attempt to demonstrate empirical order in the current chains and networks literature. The classification of governing sustainability in, of and through chains as ideal types builds on the work of others to organise the multitude of cases available to scholars and provide a conceptual basis on which further theorisation may occur of the types, conditions and trends of globalised value chain sustainability governance. Recognising the internal and external role of actors involved in sustainability governance is an important step forward. The application of 'in', 'of and 'through' approaches to our selected five frontiers of sustainability governance will instruct areas of academic debates that are most likely to further enlighten us on the kinds of integrated governance arrangements necessary for future sustainability reform through hybridised public-private economic practices.

\section{Acknowledgements}

This research was partly supported by the Interdisciplinary Research Fund (INREF) supported SUSPENSE and BESTTuna programmes of Wageningen University. We would like to thank Magnus Boström and the three reviewers for their helpful comments on an earlier draft of this paper.

\section{References}

Adriana, B., 2009. Environmental supply chain management in tourism: the case of large tour operators. J. Clean. Prod. 17, 1385-1392.

Agaba, E., Shipman, N., 2007. Public procurement reform in developing countries: the Ugandan experience. Adv. Public Procure. Pract. Innov. Knowledge-Sharing 373-391.

Anh, P.T., Bush, S.R., Mol, A.P.J., Kroeze, C., 2011. The multi-level environmental governance of Vietnamese aquaculture: global certification, national standards, local cooperatives. J. Environ. Policy Plan. 13, 373-397.

Asif, M., Searcy, C., Zutshi, A., Fisscher, O.A.M., 2013. An integrated management systems approach to corporate social responsibility. J. Clean. Prod. 56, 7-17.

Auld, G., Bernstein, S., Cashore, B., 2008. The new corporate social responsibility. Annu. Rev. Environ. Resour. 33, 413-435.

Auld, G., Gulbrandsen, L.H., 2010. Transparency in nonstate certification: consequences for accountability and legitimacy. Glob. Environ. Polit. 10, 97-119.

Aylward, D., 2004. Innovation-export linkages within different cluster models: a case study from the Australian wine industry. Prometheus 22, 423-437.

Bäckstrand, K., 2006. Multi-stakeholder partnerships for sustainable development: rethinking legitimacy, accountability and effectiveness. Eur. Env. 16, 290-306. 
Bair, J., 2008. Analysing global economic organization: embedded networks and global chains compared. Econ. Soc. 37, 339-364.

Bair, J., 2009. Frontiers of Commodity Chain Research. Stanford University Press, Stanford.

Barrientos, S.W., 2013. 'Labour chains': analysing the role of labour contractors in global production networks. J. Dev. Stud. 49, 1058-1071.

Bartley, T., 2003. Certifying forests and factories: states, social movements, and the rise of private regulation in the apparel and Forest products Fields. Polit. Soc. 31, 433-464.

Belton, B., Murray, F., Young, J., Telfer, T., Little, D.C., 2010. Passing the panda standard: a TAD off the mark? Ambio 39, 2-13.

Béné, C., 2005. The good, the bad and the ugly. Dev. Policy Rev. 23, 585-614.

Bernstein, S., Cashore, B., 2007. Can non-state global governance be legitimate? An analytical framework. Regul. Gov. 1, 1-25.

Bitzer, V., Francken, M., Glasbergen, P., 2008. Intersectoral partnerships for a sustainable coffee chain: really addressing sustainability or just picking (coffee) cherries? Glob. Environ. Change 18, 271-284.

Bolton, P., 2008. Protecting the environment through public procurement: the case of South Africa. Nat. Resour. Forum 32, 1-10.

Bolwig, S., Ponte, S., Du Toit, A., Riisgaard, L., Halberg, N., 2010. Integrating poverty and environmental concerns into value-chain analysis: a conceptual framework. Dev. Policy Rev. 28, 173-194.

Bolwig, S., Ponte, S., Riisgaard, L., du Toit, A., Halberg, N., 2011. A methodology for integrating developmental concerns into value chain analysis and interventions. Mark. Rural Poverty Upgrad. Value Chains Earthscan, Wash. D.C. 21-45.

Boons, F., Mendoza, A., 2010. Constructing sustainable palm oil: how actors define sustainability. J. Clean. Prod. 18, 1686-1695.

Boström, M., 2006a. Establishing credibility: practising standard-setting ideals in a Swedish seafood-labelling case. J. Environ. Policy \& Plan. 8, 135-158.

Boström, M., 2006b. Regulatory credibility and authority through inclusiveness: standardization organizations in cases of eco-labelling. Organization 13 345-367.

Brooks, A., 2012. Networks of power and corruption: the trade of Japanese used cars to Mozambique. Geogr. J. 178, 80-92.

Brooks, A., 2013. Stretching global production networks: the international secondhand clothing trade. Geoforum 44, 10-22.

Busch, L., Bain, C., 2004. New! Improved? The transformation of the global agrifood system. Rural. Sociol. 69, 321-346.

Busch, L., Juska, A., 1997. Beyond political economy: actor networks and the globalization of agriculture. Rev. Int. Polit. Econ. 4, 688-708.

Bush, S.R., Belton, B., Hall, D., Vandergeest, P., Murray, F.J., Ponte, S., Oosterveer, P., Islam, M.S., Mol, A.P.J., Hatanaka, M., Kruijssen, F., Ha, T.T.T., Little, D.C., Kusumawati, R., 2013. Certify sustainable aquaculture? Science 341, 1067-1068.

Carroll, A.B., Shabana, K.M., 2010. The business case for corporate social responsibility: a review of concepts, research and practice. Int. J. Manag. Rev. 12, 85-105.

Cashore, B., Auld, G., Bernstein, S., McDermott, C., 2007. Can non-state governance ratchet up' global environmental standards? Lessons from the Forest sector RECIEL 16.

Cattaneo, O., Gereffi, G., Miroudot, S., Taglioni, D., 2013. Joining, Upgrading and Being Competitive in Global Value Chains: a Strategic Framework. World Bank Policy Research Working Paper.

Cheyns, E., 2011. Multi-stakeholder initiatives for sustainable agriculture: limits of the 'inclusiveness' paradigm. In: Ponte, S., Gibbon, P., Vestergaard, J. (Eds.) Governing through Standards: Origins, Drivers and Limitations. Palgrave MacMillan, Basingstoke, pp. 210-235.

Clancy, M., 1998. Commodity chains, services and development: theory and pre liminary evidence from the tourism industry. Rev. Int. Polit. Econ. 5, 122-148.

Coe, N.M., 2012. Geographies of production II: a global production network A-Z Prog. Hum. Geogr. 36, 389-402.

Coe, N.M., Dicken, P., Hess, M., 2008. Global production networks: realizing the potential. J. Econ. Geogr. 8, 271-295.

Coe, N.M., Hess, M., 2005. The internationalization of retailing: implications for supply network restructuring in East Asia and Eastern Europe. J. Econ. Geogr. 5 449-473.

Coe, N.M., Hess, M., Yeung, H.W.-C., Dicken, P., Henderson, J., 2004. 'Globalizing' regional development: a global production networks perspective. Trans. Inst. Br: Geogr. 29, 468-484.

Crang, M., Hughes, A., Gregson, N., Norris, L., Ahamed, F., 2013. Rethinking governance and value in commodity chains through global recycling networks. Trans. Inst. Br. Geogr. 38, 12-24.

Crang, P., 1996. Displacement, consumption, and identity. Environ. Plan. A 28 $47-67$.

Cruz, L.B., Boehe, D.M., 2008. CSR in the global marketplace: towards sustainable global value chains. Manag. Decis. 46, 1187-1209.

Dalal-Clayton, B., Sadler, B., 2014. Sustainability Appraisal: a Sourcebook and Reference Guide to International Experience. Routledge.

Dauvergne, P., Neville, K.J., 2009. The changing north-south and south-south political economy of biofuels. Third World Q. 30, 1087-1102.

Daviron, B., Gibbon, P., 2002. Global commodity chains and African Export agriculture. J. Agrar. Change 2, 137-161.

Davis, P.S., Robinson, R.B., Pearce, J.A., Park, S.H., 1992. Business unit relatedness and performance: a look at the pulp and paper industry. Strat. Mgmt. J. 13, 349-361.

De Bakker, F., Nijhof, A., 2002. Responsible chain management: a capability assessment framework. Bus. Strat. Env. 11, 63-75.
De Marchi, V., Maria, E.D., Micelli, S., 2013. Environmental strategies, upgrading and competitive advantage in global value chains, Bus. Strat. Env. 22, 62-72.

Dennis Wei, Y., Liefner, I., Miao, C.-H., 2011. Network configurations and R\&D activities of the ICT industry in Suzhou municipality, China. Geoforum 42, 484-495.

Derudder, B.E.N., Witlox, F., 2010. World cities and global commodity chains: an introduction. Glob. Netw. 10, 1-11.

Dolan, C., Humphrey, J., 2000. Governance and trade in fresh vegetables: the impact of UK supermarkets on the African horticulture industry. J. Dev. Stud. 37, 147-176.

Ebeling, J., Yasué, M., 2009. The effectiveness of market-based conservation in the tropics: forest certification in Ecuador and Bolivia. J. Environ. Manag. 90, $1145-1153$.

Elgert, L., 2012. Certified discourse? The politics of developing soy certification standards. Geoforum 43, 295-304.

Falkner, R., 2003. Private environmental governance and international relations: exploring the links. Glob. Environ. Polit. 3, 72-87.

Fine, B., 1993. Modernity, urbanism, and consumption: a comment. Environ. Plan. D: Soc. Space 11, 599-601.

Fine, B., Heasman, M., Wright, J., 1996. Consumption in the Age of Affluence: the World of Food. Routledge, London.

Fine, B., Leopold, E., 1993. The World of Consumption. Routledge, London.

Foley, P., 2012. The political economy of Marine Stewardship Council certification: processors and access in Newfoundland and Labrador's inshore shrimp industry. J. Agrar. Change 12, 436-457.

Fortin, E., Richardson, B., 2013. Certification schemes and the governance of land: enforcing standards or enabling scrutiny? Globalizations 10, 141-159.

Fransen, L.W., Kolk, A., 2007. Global rule-setting for business: a critical analysis of multi-stakeholder standards. Organization 14, 667-684.

Friedmann, H., 1993. The political economy of food: a global crisis. New. Left Rev. 197, 29-57.

Fuchs, D., Kalfagianni, A., 2012. The Effectiveness of Private Environmental Governance, 23. In: Handbook of Global Environmental Politics, p. 298.

Gereffi, G., 1994. The organization of buyer-driven global commodity chain: how U.S. retailers shape overseas production networks. In: Gereffi, G., Korzeniewicz, M. (Eds.), Commodity Chains and Global Capitalism. Praeger, Westport, pp. 95-122.

Gereffi, G., 1995. Global production systems and third world development. In: Stallings, B. (Ed.), Global Change, Regional Response: the New International Context of Development. Canbridge University Press, Cambridge, pp. 100-142.

Gereffi, G., Humphrey, J., Kaplinsky, R., Sturgeon, T.J., 2001. Introduction: globalisation, value chains and development. IDS Bull. 32, 1-8.

Gereffi, G., Humphrey, J., Sturgeon, T., 2005. The governance of global value chains. Rev. Int. Polit. Econ. 12, 78-104.

Gibbon, P., Bair, J., Ponte, S., 2008. Governing global value chains: an introduction. Econ. Soc. 37, 315-338.

Gibbon, P., Ponte, S., 2005. Trading Down. Africa, Value Chains, and the Global Economy. Temple University Press, Philadelphia.

Giuliani, E., 2007. The selective nature of knowledge networks in clusters: evidence from the wine industry. J. Econ. Geogr. 7, 139-168.

Glennie, P.D., Thrift, N.J., 1993. Modern consumption: theorising commodities and consumers. Environ. Plan. D: Soc. Space 11, 603-606.

Glin, L.C., Oosterveer, P., Mol, A.P.J., Vodouhe, S.D., 2012. Governing the transnational organic cotton network from Benin global networks, 12, 333-354.

Gold, S., Seuring, S., Beske, P., 2010. Sustainable supply chain management and inter-organizational resources: a literature review. Corp. Soc. Responsib. Environ. Mgmt. 17, 230-245.

Goodman, D., Watts, M., 1997. Globalising Food: Agrarian Questions and Global Restructuring. Routledge, London/New York.

Gui, L., Atasu, A., Ergun, Ö., Toktay, L.B., 2013. Implementing extended producer responsibility legislation. J. Indust. Ecol. 17, 262-276.

Gulbrandsen, L.H., 2009. The emergence and effectiveness of the Marine Stewardship Council. Mar. Policy 33, 654-660.

Gulbrandsen, L.H., 2013. Dynamic governance interactions: evolutionary effects of state responses to non-state certification programs. Regul. Gov..

Gupta, A., 2008. Transparency under Scrutiny: Information disclosure in global environmental governance. Glob. Environ. Polit. 8, 1-7.

Gupta, A., Mason, M., 2014. Transparency in Global Environmental Governance: a Critical Perspective. MIT, Cambridge (Mass.)

Ha, T.T.T., Bush, S.R., 2010. Transformations of Vietnamese shrimp aquaculture policy: empirical evidence from Ca Mau Province, the Mekong Delta. Environ. Plan. C: Gov. Policy 28, 1101-1119.

Handfield, R.B., Nichols, E.L., 1999. Introduction to Supply Chain Management. prentice Hall, New-Jersey.

Hess, M., 2004. 'Spatial'relationships? Towards a reconceptualization of embedded ness. Prog. Hum. Geogr. 28, 165-186.

Ho, L.W.P., Dickinson, N.M., Chan, G.Y.S., 2010. Green procurement in the Asian public sector and the Hong Kong private sector. Nat. Resour. Forum 34, 24-38.

Hopkins, M. 2004. Corporate Social Responsibility: an Issues Paper. Internationa Labour Organization, Geneva.

Hopkins, T.K., Wallerstein, I., 1977. Patterns of development of the modern worldsystem. Rev. (Fernand Braudel Cent. 1, 111-145.

Hughes, A., Reimer, S., 2004a. Geographies of Commodity Chains, Routledge Studies in Human Geographies. Routledge, London and New York. 
Hughes, A., Reimer, S., 2004b. Introduction. In: Hughes, A.a.S.R. (Ed.), Geographies of Commodity Chains. Routledge, London and New York, pp. 1-16.

Hughes, A., Wrigley, N., Buttle, M., 2008. Global production networks, ethical campaigning, and the embeddedness of responsible governance. J. Econ. Geogr. 8, 345-367.

Humphrey, J., Schmitz, H., 2000. Governance and Upgrading: Linking Industrial Cluster and Global Value Chain Research.

Humphrey, J., Schmitz, H., 2002. How does insertion in global value chains affect upgrading in industrial clusters? Reg. Stud. 36, 1017-1027.

Jacquet, J., Pauly, D., Ainley, D., Holt, S., Dayton, P., Jackson, J., 2010. Seafood stewardship in crisis. Nature 467, 28-29.

Jamali, D., Mirshak, R., 2007. Corporate social responsibility (CSR): theory and practice in a developing country context. J. Bus. Ethics 72, 243-262.

Jeppesen, S., Hansen, M.W., 2004. Environmental upgrading of third world enterprises through linkages to transnational corporations. Theoretical perspectives and preliminary evidence. Bus. Strat. Env. 13, 261-274.

Jonell, M., Phillips, M., Rönnbäck, P., Troell, M., 2013. Eco-certification of farmed seafood: will it make a difference? Ambio 1-16.

Kalfagianni, A., Pattberg, P., 2011. The Effectiveness of Transnational Rule-setting Organisations in Global Sustainability Politics: an Analytical Framework. Global governance working paper.

Kaplinsky, R., 2000. Globalisation and unequalisation: what can be learned from value chain analysis? J. Dev. Stud. 37, 117-146.

Kaplinsky, R., Farooki, M., 2010. Global value chains, the crisis, and the shift of markets from North to south. Glob. Value Chains a Postcrisis World; A Dev. Perspect. 125-154.

Kataoka, A., 2006. IGPN and Green Purchasing Activities in Asia. https://www.igpn. org/workshop/pdf/Akira\%20Kataoka\%20-\%20India\%20workshop\%20March\% 2006.pdf.

Kautto, P., 2006. New instruments - old practices? The implications of environmental management systems and extended producer responsibility for design for the environment. Bus. Strat. Env. 15, 377-388.

Khiem, N.T., Bush, S.R., Chau, H.H., Loc, V.T.T., 2010. Upgrading Small-holders in the Vietnamese Pangasius Value Chain. IDRC, An Giang University. ODI Grant Number RO334. Online: http://www.enp.wur.nl/NR/rdonlyres/AB5138A3-0101-441D8C5C-739D6930DD0B/115093/UpgradingPangasiusFINAL.pdf. Long Xuyen.

Klooster, D., 2005. Environmental certification of forests: the evolution of environmental governance in a commodity network. J. Rural Stud. 21, 403-417.

Leslie, D., Reimer, S., 1999. Spatializing commodity chains. Prog. Hum. Geogr. 23, 401-420.

Li, L., Geiser, K., 2005. Environmentally responsible public procurement (ERPP) and its implications for integrated product policy (IPP). J. Clean. Prod. 13, 705-715.

Lifset, R., Atasu, A., Tojo, N., 2013. Extended producer responsibility: national, international, and practical perspectives. J. Indust. Ecol. 17, 162-166.

Macdonald, K., 2014. The Politics of Global Supply Chains. Polity, Cambridge and Malden.

Marsden, T.K., 2004. Theorising food quality: some issues in understanding its competitive production and regulation. In: Harvey, M., McMeekin, A., Warde, A. (Eds.), Qualities of Food. Manchester University Press, pp. 129-155.

Martin, R., Sunley, P., 2003. Deconstructing clusters: chaotic concept or policy panacea? J. Econ. Geogr. 3, 5-35.

Mayer, F., Gereffi, G., 2010. Regulation and economic globalization: prospects and limits of private governance. Bus. Polit. 12.

McCarthy, J.F., Gillespie, P., Zen, Z., 2012. Swimming upstream: local Indonesian production networks in "Globalized" Palm oil production. World Dev. 40, 555-569.

McMichael, P., 1994. Global restructuring: some lines of inquiry. In: McMichael, P. (Ed.), The Global Restructuring of Agro-food Systems. Cornell University Press, Ithaca and London, pp. 277-300.

Miller, A.M.M., Bush, S.R., 2014. Authority without credibility? Competition and conflict between ecolabels in Tuna fisheries. J. Clean. Prod..

Miller, F., Osbahr, H., Boyd, E., Thomalla, F., Bharwani, S., Ziervogel, G., Walker, B., Birkmann, J., Van der Leeuw, S., Rockström, J., Hinkel, J., Downing, T., Folke, C., Nelson, D., 2010. Resilience and vulnerability: complementary or conflicting concepts? Ecol. Soc. 11 [online] URL: http://www.ecologyandsociety.org/vol15/ iss13/art11/.

Mitchell, J., Coles, C., 2011. Markets and Rural Poverty. Upgrading in Value Chains Routledge, London.

Mol, A., 2008. Environmental Reform in the Information Age. The Contours of Informational Governance Cambridge University Press, Cambridge.

Mol, A.P., 2010. The future of transparency: power, pitfalls and promises. Glob. Environ. Polit. 10, 132-143.

Mol, A.P., 2011. China's ascent and Africa's environment. Glob. Environ. Change 21, $785-794$.

Mol, A.P.J., 2015. Transparency and value chain sustainability. J. Clean. Prod. 107, 154-161. http://dx.doi.org/10.1016/j.jclepro.2013.11.012.

Morgan, K., Sonnino, R., 2007. Empowering consumers: the creative procurement of school meals in Italy and the UK. Int. J. Consumer Stud. 31, 19-25.

Murdoch, J., 2000. Networks - a new paradigm of rural development? J. Rural Stud. 20, 407-419.

Murphy, J.T., 2008. Economic geographies of the global south: missed opportunities and promising intersections with development studies. Geogr. Compass 2, 851-873.

Mutersbaugh, T., 2005. Fighting standards with standards: harmonization, rents, and social accountability in certified agrofood networks. Environ. Plan. A 37, 2033-2051.
Nadvi, K., 2008. Global standards, global governance and the organization of global value chains. J. Econ. Geogr. 8, 323-343.

Negro, S.O., Vasseur, V., Sark, W.G.V., Hekkert, M.P., 2012. Solar eclipse: the rise and'dusk'of the Dutch PV innovation system. Int. J. Technol. Policy Manag. 12, 135-157.

Nijhof, A., Jeurissen, R., 2006. Editorial: a sensemaking perspective on corporate social responsibility: introduction to the special issue. Bus. Ethics: A Eur. Rev. 15, 316-322.

Orlitzky, M., Siegel, D.S., Waldman, D.A., 2011. Strategic corporate social responsibility and environmental sustainability. Bus. Soc. 50, 6-27.

Orsato, R., 2009. Sustainable Strategies-when Does it Pay to Be Green. Palgrave Macmillan, Basingstoke.

Ouma, S., 2010. Global standards, local realities: private agrifood governance and the restructuring of the Kenyan horticulture industry. Econ. Geogr. 86, $197-222$.

Overdevest, C., Rickenbach, M.G., 2006. Forest certification and institutional governance: an empirical study of forest stewardship council certificate holders in the United States. For. Policy Econ. 9, 93-102.

Palpacuer, F., 2010. For an institutional approach to corporate governance: making sense of NGO campaigns in global apparel chains. Rev. l'organisation Responsab. 4, 5-18.

Parikka-Alhola, K., 2008. Promoting environmentally sound furniture by green public procurement. Ecol. Econ. 68, 472-485.

Partzsch, L., 2011. The legitimacy of biofuel certification. Agric. Hum. Values 28, 413-425.

Pattberg, P., 2006. Private governance and the South: lessons from global forest politics. Third World Q. 27, 579-593.

Pickles, J., Smith, A., Bucek, M., Roukova, P., Begg, R., 2006. Upgrading, changing competitive pressures, and diverse practices in the East and Central European apparel industry. Environ. Plan. A 38, 2305.

Ponte, S., 2008. Greener than thou: the political economy of fish ecolabeling and its local manifestations in South Africa. World Dev. 36, 159-175.

Ponte, S., 2009. Governing through quality: conventions and supply relations in the value chain for South African wine. Sociol. Rural. 49, 236-257.

Ponte, S., 2014. 'Roundtabling' sustainability: lessons from the biofuel industry. Geoforum 54, 261-271.

Ponte, S., Cheyns, E., 2013. Voluntary standards, expert knowledge and the governance of sustainability networks. Glob. Netw. 13, 459-477.

Ponte, S., Ewert, J., 2009. Which way is "Up" in upgrading? Trajectories of change in the value chain for south African wine. World Dev. 37, 1637-1650.

Ponte, S., Gibbon, P., 2005. Quality standards, conventions and the governance of global value chains. Econ. Soc. 34, 1-31.

Ponte, S., Gibbon, P., Vestergaard, J., 2011. Governing through Standards. Origins, Drivers and Limitations. Palgrave Macmillan, Houndmills and New York.

Ponte, S., Sturgeon, T., 2013. Explaining governance in global value chains: a modular theory-building effort. Rev. Int. Polit. Econ. 1-29.

Porter, G., 1999. Trade competition and pollution standards: "race to the bottom" or "Stuck at the bottom". J. Environ. Dev. 8, 133-151.

Porter, M.E., 1985. Competitive Advantages. Creating and Sustaining Superior Performance.

Porter, M.E., 2000. Location, competition, and economic development: local clusters in a global economy. Econ. Dev. Q. 14, 15-34.

Porter, M.E., Kramer, M.R., 2006. Strategy \& society. The link between competitive advantage and corporate social responsibility. Harv. Bus. Rev. Dec. 2006 1-15.

Porter, M.E., Kramer, M.R., 2011. Creating Shared Value. How to reinvent capitalismand unleash a wave of innovation and growth. Harv. Bus. Rev. 1-17. January-February 2011.

Porter, M.E., Linde, C.v.d, 1995. Toward a new conception of the environmentcompetitiveness relationship. J. Econ. Perspect. 9, 97-118.

Preuss, L., 2009. Addressing sustainable development through public procurement: the case of local government. Supply Chain Manag. An Int. J. 14, 213-223.

Raghuram, P., 2004. Initiating the commodity chain: south Asian women and fashion in the diaspora. In: Hughes, A., Reimer, S. (Eds.), Geographies of Commodity Chains. Routledge, London, pp. 120-136.

Raikes, P., Jensen, M.F., Ponte, S., 2000. Global commodity chain analysis and the French filière approach: comparisons and critique. Econ. Soc. 29, 390-417.

Reardon, T., Henson, S., Berdegué, J., 2007. 'Proactive fast-tracking' diffusion of supermarkets in developing countries: implications for market institutions and trade. J. Econ. Geogr. 7, 399-431.

Robinson, B.H., 2009. E-waste: an assessment of global production and environmental impacts. Sci. Total Environ. 408, 183-191.

Romero, I., Tejada, P., 2011. A multi-level approach to the study of production chains in the tourism sector. Tour. Manag. 32, 297-306.

Rossi, A., Luinstra, A., Pickles, J., 2013. Towards Better Work: Understanding Labour in Apparel Global Value Chains. Palgrave Macmillan, London.

Rwelamila, P.D., Talukhaba, A.A., Ngowi, A.B., 2000. Project procurement systems in the attainment of sustainable construction. Sust. Dev. 8, 39-50.

Sassen, S., 2010. Global inter-city networks and commodity chains: any intersections? Glob. Netw. 10, 150-163.

Scarlat, N., Dallemand, J.-F., 2011. Recent developments of biofuels/bioenergy sustainability certification: a global overview. Energy Policy 39, 1630-1646.

Schader, C., Grenz, J., Meier, M.S., Stolze, M., 2014. Scope and precision of sustainability assessment approaches to food systems. Ecol. Soc. 19, 42.

Schouten, G., Glasbergen, P., 2011. Creating legitimacy in global private governance: the case of the roundtable on sustainable palm oil. Ecol. Econ. 70, 1891-1899. 
Schouten, G., Leroy, P., Glasbergen, P., 2012. On the deliberative capacity of private multi-stakeholder governance: the roundtables on responsible soy and sustainable palm oil. Ecol. Econ. 83, 42-50.

Seuring, S., Gold, S., 2013. Sustainability management beyond corporate boundaries: from stakeholders to performance. J. Clean. Prod. 56, 1-6.

Seuring, S., Müller, M., 2008. From a literature review to a conceptual framework for sustainable supply chain management. J. Clean. Prod. 16, 1699-1710.

Sigala, M., 2008. A supply chain management approach for investigating the role of tour operators on sustainable tourism: the case of TUI. J. Clean. Prod. 16, 1589-1599.

Silva-Castañeda, L., 2012. A forest of evidence: third-party certification and multiple forms of proof - a case study of oil palm plantations in Indonesia. Agric. Hum. Values 29, 361-370.

Simon, H., 2000. Public administration in today's world of organisations and markets. Political Sci. Polit. 33, 749-756.

Singh, J., 2010. Public Procurement of Energy Efficiency Services: Lessons from International Experience. World Bank-free PDF.

Smith, N.C., 2003. Corporate Social Responsibility: not Whether, but How? London Business School, London.

Sonnino, R., McWilliam, S., 2011. Food waste, catering practices and public procurement: a case study of hospital food systems in Wales. Food Policy 36, $823-829$.

Srivastava, S.K., 2007. Green supply-chain management: a state-of-the-art literature review. Int. J. Manag. Rev. 9, 53-80.

Staritz, C., Reis, G., 2013. Global Value Chains, Economic Upgrading, and Gender: Case Studies of the Horticulture, Tourism, and Call Center Industries. World Bank.

Sturgeon, T.J., 2009. From commodity chains to value Chains: Interdisciplinary theory building in an age of globalization. In: Bair, J. (Ed.), Frontiers of Commodity Chain Research. Stanford University Press, Stanford, pp. 110-135.

Sturgeon, T.J., Gereffi, G., 2009. Measuring success in the global economy: International trade, industrial upgrading and business function outsourcing in global value chains. Transnatl. Corp. 18, 1.
Talbot, J.M., 2009. The comparative advantages of tropical commodity chain analysis. In: Bair, J. (Ed.), Frontiers of Commodity Chain Research. Stanford University Press, Stanford, pp. 93-109.

Tallman, S., Jenkins, M., Henry, N., Pinch, S., 2004. Knowledge, clusters, and competitive advantage. Acad. Manag. Rev. 29, 258-271.

Taylor, P.L., 2005. In the market by not of it: fair trade coffee and Forest Stewardship Council certification as market-based social change. World Dev. 33, 129-147.

Tejada, P., Santos, F.J., Guzmán, J., 2011. Applicability of global value chains analysis to tourism: issues of governance and upgrading. Serv. Indust. J. 31, 1627-1643.

Vandergeest, P., Unno, A., 2012. A new extraterritoriality? Aquaculture certification, sovereignty, and empire. Polit. Geogr. 31, 358-367.

Vind, I., Fold, N., 2010. City networks and commodity chains: identifying global flows and local connections in Ho Chi Minh City. Glob. Netw. 10, 54-74.

Vogel, D., 2010. The private regulation of global corporate conduct. Bus. Soc. 49, 68-87.

Wagemans, F.A.J., Koppen, C.S.A.v., Mol, A.P.J., 2013. The effectiveness of socially responsible investment: a review. J. Integr. Environ. Sci. 10, 235-252.

Whatmore, S., Thorne, L., 1997. Nourishing networks. Alternative geographies of food. In: Goodman, D., Watts, Michael (Eds.), Globalizing Food. Agrarian Questions and Global Restructuring. Routledge, London, pp. 287-304.

Wheeler, D. Colbert, B., Freeman, R.E., 2003. Focusing on value: reconciling corporate social responsibility, sustainability and a stakeholder approach in a network world. J. General Manag. 28, 1-28.

Windsor, D., 2006. Corporate social responsibility: three key approaches. J. Manag. Stud. 43, 93-114.

Yeung, H.W.-c., Coe, N.M., 2014. Toward a dynamic theory of global production networks. Econ. Geogr. (forthcoming).

Yu, J., Jackson, R., 2011. Regional innovation clusters: a critical review. Growth Change 42, 111-124. 